Article

\title{
Lutein, a Natural Carotenoid, Induces $\alpha-1,3-$ Glucan Accumulation on the Cell Wall Surface of Fungal Plant Pathogens
}

\author{
Junnosuke Otaka ${ }^{\dagger}$, Shigemi Seo and Marie Nishimura * \\ Institute of Agrobiological Sciences, National Agriculture and Food Research Organization, 2-1-2 Kannondai, \\ Tsukuba, Ibaraki 305-8602, Japan; o.junnosuke@gmail.com (J.O.); sseo71@affrc.go.jp (S.S.) \\ * Correspondence: marie@affrc.go.jp; Tel.: +81-29-838-8461 \\ † Present Address: Institute of Physical and Chemical Research, 1-2 Hirosawa, Wako, Saitama 351-0106, Japan \\ Academic Editor: Marcello Iriti \\ Received: 18 January 2016; Accepted: 25 July 2016; Published: 28 July 2016
}

\begin{abstract}
Glucan, a component of the fungal cell wall, is a refractory polysaccharide for most plants. Previously, we showed that various fungal plant pathogens masked their cell wall surfaces with $\alpha-1,3$-glucan to evade plant immunity. This surface accumulation of $\alpha-1,3$-glucan was infection specific, suggesting that plant factors might induce its production in fungi. Through immunofluorescence observations of fungal cell walls, we found that carrot (Daucus carota) extract induced the accumulation of $\alpha-1,3$-glucan on germlings in Colletotrichum fioriniae, a polyphagous fungal pathogen that causes anthracnose disease in various dicot plants. Bioassay-guided fractionation of carrot leaf extract successfully identified two active substances that caused $\alpha-1,3$-glucan accumulation in this fungus: lutein, a carotenoid widely distributed in plants, and stigmasterol, a plant-specific membrane component. Lutein, which had a greater effect on C. fioriniae, also induced $\alpha-1,3$-glucan accumulation in other Colletotrichum species and in the phylogenetically distant rice pathogen Cochliobolus miyabeanus, but not in the rice pathogen Magnaporthe oryzae belonging to the same phylogenetic subclass as Colletotrichum. Our results suggested that fungal plant pathogens reorganize their cell wall components in response to specific plant-derived compounds, which these pathogens may encounter during infection.
\end{abstract}

Keywords: $\alpha-1,3$-glucan; bioassay-guided isolation; carotenoid; cell wall; fungal pathogen; sterol

\section{Introduction}

Cell walls are essential for fungi to maintain their structure and to protect the cells from the environment. The fungal cell wall is mainly composed of polysaccharides such as glucans, chitin/chitosan and mannan. In filamentous ascomycete fungi, the structural core of the cell wall is generally composed of branched $\beta-1,3$-glucan and chitin. This core is embedded in amorphous polysaccharides, e.g., $\alpha-1,3$-glucan, and the composition of the amorphous polysaccharides may vary by fungal class/genus [1-3]. Intensive studies on medically important fungi have revealed that the composition and localization of cell wall polysaccharides change in response to environmental conditions such as temperature [3]. Recently, we have performed immunohistochemical studies of the organization of cell wall polysaccharides in phylogenetically distant plant pathogenic fungi: the ascomycetes Magnaporthe oryzae and Cochliobolus miyabeanus and the basidiomycete Rhizoctonia solani [4,5]. Our studies revealed that these fungi accumulate $\alpha-1,3$-glucan on their surfaces to mask the cell walls during infection. Because $\alpha-1,3$-glucan is a refractory polysaccharide for plants, it is very likely that the surface accumulation of $\alpha-1,3$-glucan protects the fungal cell walls from plant antifungal agents, such as cell wall digesting enzymes, which fungi encounter during infection [4]. 
This idea was supported experimentally; $M$. oryzae lacking surface $\alpha$-1,3-glucan was very sensitive to a cell digesting enzyme. In addition, transgenic rice plants expressing a bacterial $\alpha-1,3$-glucanase exhibited resistance towards $M$. oryzae, C. miyabeanus, and R. solani [5]. These results indicated that surface accumulation of $\alpha-1,3$-glucan facilitates infection in these pathogenic fungi. We were interested in the fact that these fungal plant pathogens accumulate $\alpha-1,3$-glucan on the cell wall specifically during infection but not during vegetative growth [4,5]. This implied that the fungi recognize host factor(s) to induce the surface accumulation of $\alpha-1,3$-glucan. Indeed, we found that recognition of a cutin monomer, 1,16-hexadecanediol, induced the accumulation of $\alpha$-1,3-glucan on the cell wall surface of $M$. oryzae by activating the cell wall integrity mitogen-activated protein kinase signal transduction pathway [4]. However, the cutin monomer caused very little surface accumulation of $\alpha-1,3$-glucan in $C$. miyabeanus and $R$. solani [5], suggesting that these two pathogens respond to unknown plant factor(s). In this study, we describe the isolation and identification of novel host factors that induce the surface accumulation of $\alpha-1,3$-glucan in the fungal plant pathogens such as $C$. miyabeanus and Colletotrichum species.

\section{Results}

\subsection{Isolation and Identification of Inducers of $\alpha-1,3-$ Glucan Accumulation in Colletotrichum Fioriniae from Carrot Leaves Subsection}

In the course of our immunohistological study of fungal cell walls, we noticed that Colletotrichum fioriniae, which causes anthracnose in a broad range of dicot plants [6,7], accumulated detectable amounts of $\alpha-1,3$-glucan on the cell wall when the fungus was grown in medium containing carrot leaf extract (Figure 1). In contrast, $\alpha$-1,3-glucan was hardly detected in the fungal cell wall when the fungus was incubated in medium that did not contain carrot extract (Figure 1).
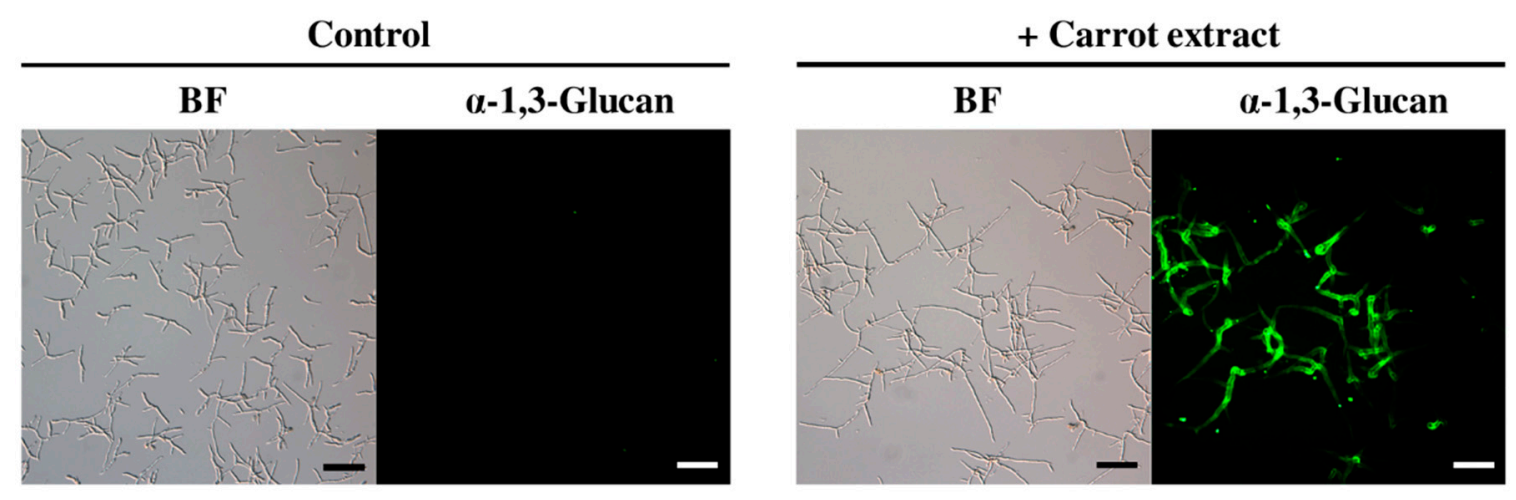

Figure 1. Immunofluorescent detection of $\alpha-1,3-$ glucan on the cell wall of Colletotrichum fioriniae. $\alpha-1,3$-glucan was clearly visible on the cell wall of the fungi incubated in $0.24 \%$ potato dextrose broth (PDB) containing carrot extract (in $1 \%$ ethanol and $0.1 \%$ dimethyl sulfoxide (DMSO)). The $0.24 \%$ PDB solution containing $1 \%$ ethanol and $0.1 \%$ DMSO was used as a control. BF (left panels), bright field microscopy; “ $\alpha$-1,3-glucan" (right panels), fluorescence microscopy. Scale bar, $20 \mu \mathrm{m}$. More than 300 germinated fungal conidia were observed; representative images are shown. Experiments were repeated three times.

We confirmed that 1,16-hexadecanediol, a known inducer of $\alpha$-1,3-glucan accumulation in M. oryzae [4], did not cause the accumulation of $\alpha-1,3$-glucan on the $C$. fioriniae cell wall (Figure S1). Based on these findings, we speculated that carrot leaf extract might contain novel inducer(s) of $\alpha-1,3$-glucan accumulation that affect $C$. fioriniae. To identify the active substance(s) responsible for this $\alpha-1,3$-glucan accumulation, we performed bioassay-guided fractionation of the carrot leaf extract. The lyophilized carrot leaves were extracted with a dichloromethane-methanol mixture and divided into hexane-, ethyl acetate-, butanol- and water-soluble layers (Figure 2). 


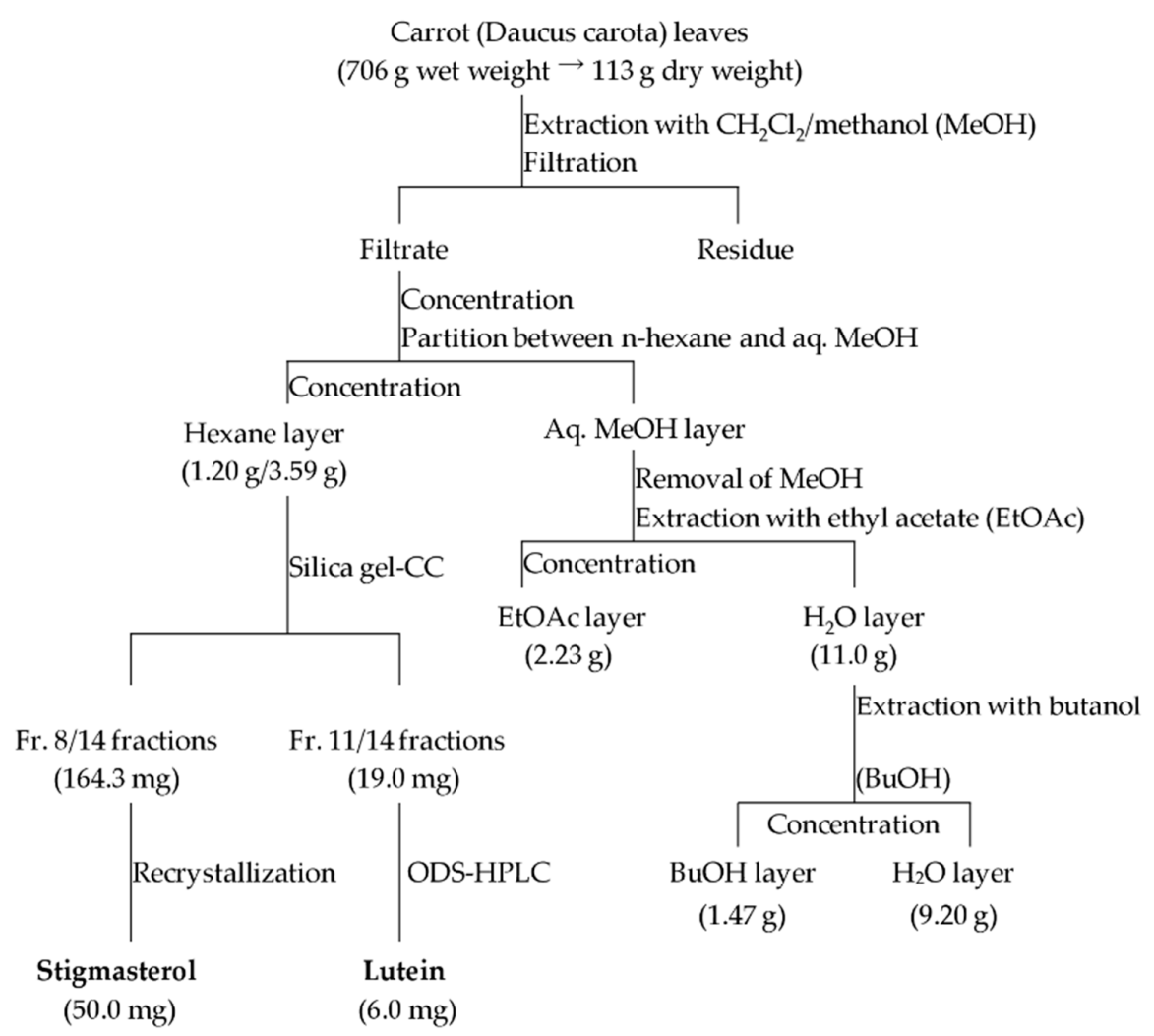

Figure 2. Isolation procedure of active substances from carrot leaves. Each fraction was tested for induction activity of $\alpha-1,3$-glucan on the surface in Colletotrichum fioriniae.

Each layer was mixed with fungal conidia and incubated on a cover glass, and the accumulation of $\alpha-1,3$-glucan on the fungal cell wall was observed using a fluorophore-conjugated $\alpha$-1,3-glucan antibody. The strongest activity was found in the hexane layer; this activity was separated into two active fractions using silica gel chromatography. Further purification of the two fractions led to the isolation of an active compound for each. ${ }^{1} \mathrm{H}$ - and ${ }^{13} \mathrm{C}-\mathrm{NMR}$ analyses revealed that the active compound with the highest activity was lutein (Figure 3; Figure S4), and the modest activity was assigned to stigmasterol (Figure 3).

\section{(A)}

Lutein<smiles>CC1=C[C@H](O)C[C@](C)(P)[C@H]1/C=C/C(C)=C/C=C/C(Br)=C/C=C/C=C(C)/C=C/C=C(C)/C=C/C1=C(C)C[C@@H](O)C[C@]1(C)F</smiles>

Stigmasterol

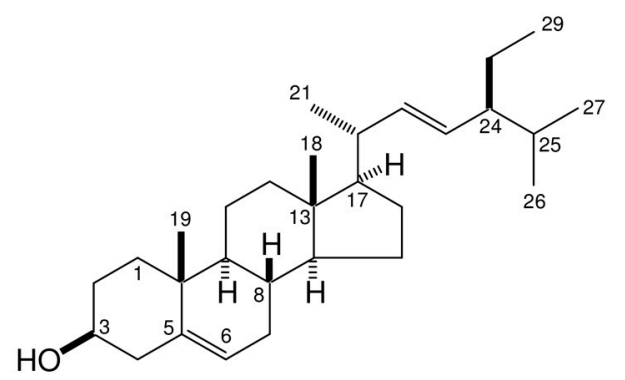

Figure 3. Cont. 
(B)

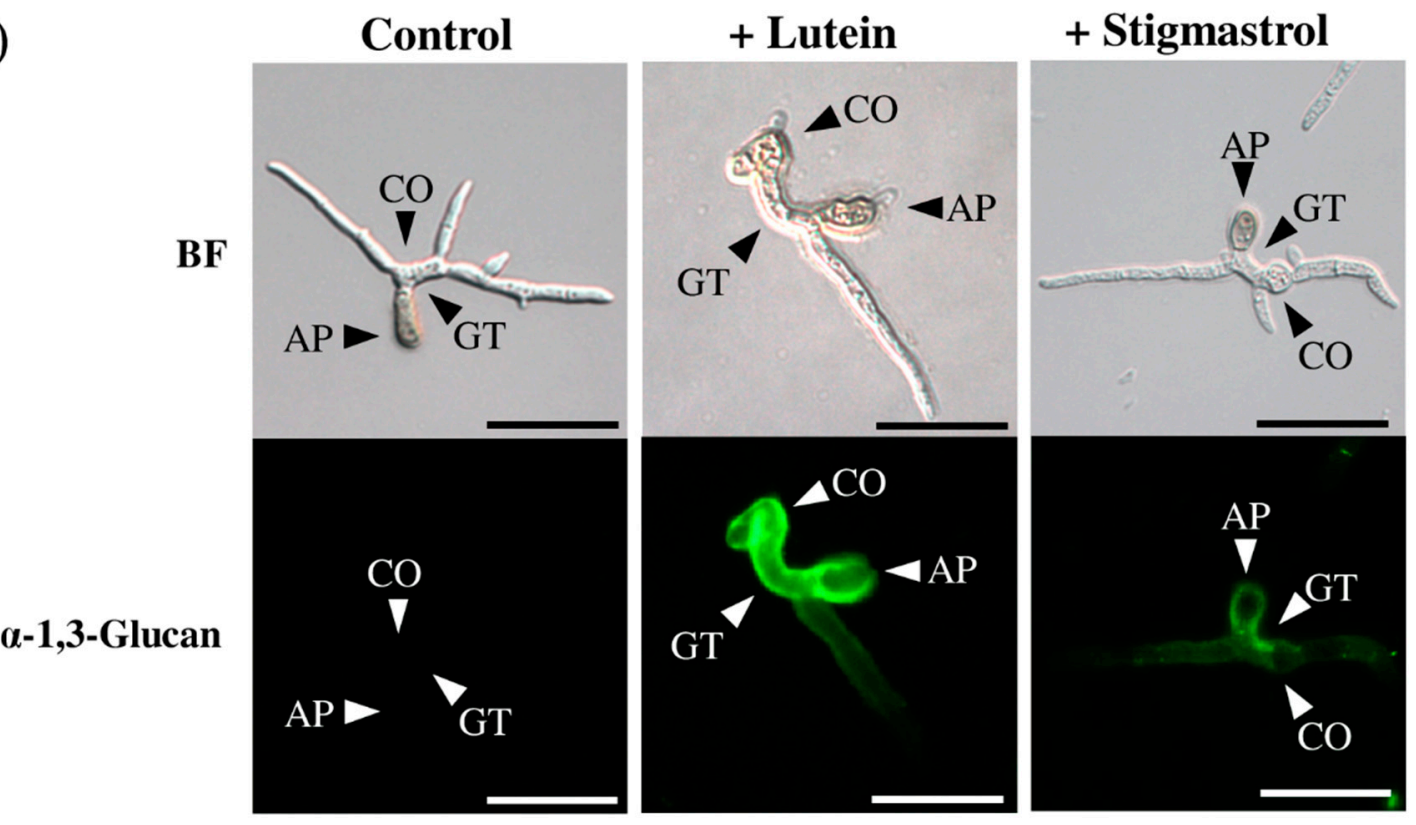

Figure 3. Immunofluorescent detection of $\alpha-1,3$-glucan on the cell wall of Colletotrichum fioriniae in the presence of active substances from carrot leaves. (A) The structures of lutein and stigmasterol; (B) Accumulation of surface $\alpha$-1,3-glucan in the presence of lutein $(10 \mu \mathrm{M})$ and stigmasterol $(50 \mu \mathrm{M})$. The fungal conidia were incubated in $0.24 \%$ potato dextrose broth (PDB) containing lutein/stigmasterol dissolved in $1 \%$ ethanol and $0.1 \%$ dimethyl sulfoxide (DMSO). Control; $0.24 \%$ PDB solution containing $1 \%$ ethanol and $0.1 \%$ DMSO. BF, bright field microscopy; “ $\alpha$-1,3-glucan”, fluorescence microscopy. $\mathrm{AP}$, appressoria; CO, conidia; GT, germ tubes. Scale bar, $20 \mu \mathrm{m}$. More than 300 germinated fungal conidia were observed for each sample. Representative images at $12 \mathrm{~h}$ after incubation are shown. Experiments were repeated three times.

We further tested whether $\beta$-carotene and ergosterol, structurally similar compounds to lutein and stigmasterol, respectively, induced surface $\alpha-1,3$-glucan accumulation in $C$. fioriniae. As shown in Figure S2, $\alpha$-1,3-glucan accumulation was undetectable in the presence of $\beta$-carotene and low in the presence of ergosterol. This suggested that $C$. fioriniae specifically responded to lutein.

\subsection{Lutein Induced the Accumulation of $\alpha-1,3-$ Glucan on the Surface in Various Colletotrichum Species}

To examine the inductive effect of lutein in other Colletotrichum species, we incubated conidia of C. orbiculare, C. gloeosporioides, C. chrysanthemi, and C. godetiae with or without lutein on glass coverslips, and appressorium-forming conidia were immunofluorescently stained for $\alpha-1,3$-glucan on the cell wall. As shown in Figure 4, fluorescence was hardly detected on the cell walls of appressorium-forming conidia in these Colletotrichum strains when they were incubated in the absence of lutein. In contrast, fluorescence was detectable on those incubated with lutein, although the fluorescence was most intense on C. gloeosporioides, C. chrysanthemi and C. godetiae, and relatively weak on C. orbiculare (Figure 4).

Similar to C. fioriniae, the species C. gloeosporioides and C. godetiae infect a broad range of plants. C. chrysanthemi and C. orbiculare, in contrast, show preferences for asterids and cucurbits, respectively [6-8]. This result indicated that the surface accumulation of $\alpha-1,3-$ glucan was induced by lutein in these Colletotrichum species regardless of the preferred host plants. 


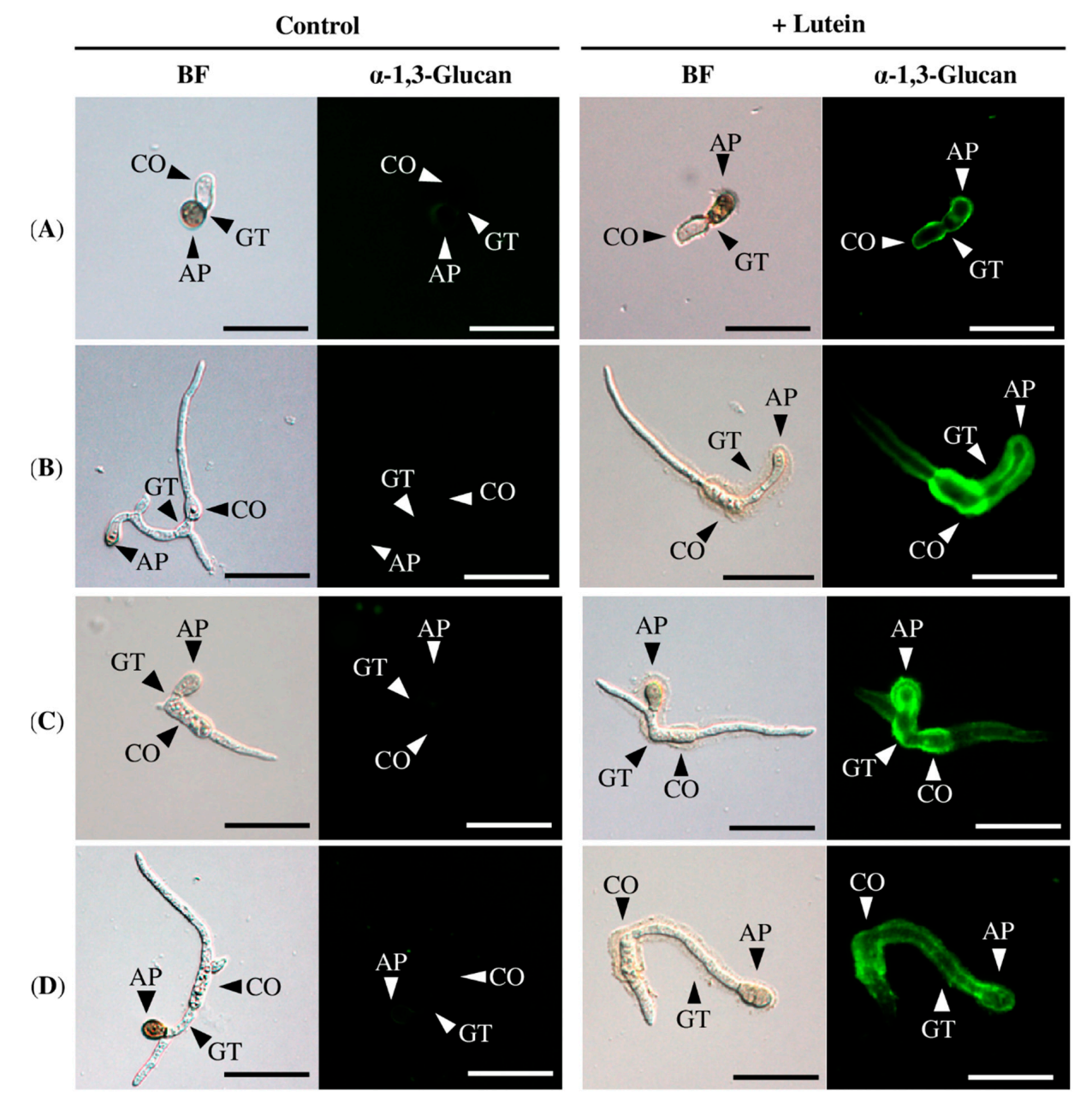

Figure 4. Surface accumulation of $\alpha-1,3$-glucan on the cell walls of Colletotrichum species in the presence of lutein. (A) C. orbiculare, (B) C. gloeosporoides, (C) C. chrysanthemi, (D) C. godetiae. Fungal conidia were incubated in $0.24 \%$ potato dextrose broth (PDB) containing lutein $(25 \mu \mathrm{M}$ in $1 \%$ ethanol and $0.1 \%$ dimethyl sulfoxide [DMSO]) for $12 \mathrm{~h}$ and subjected to immunofluorescent detection of cell wall $\alpha-1$,3-glucan. Control, $0.24 \%$ PDB containing $1 \%$ ethanol and $0.1 \%$ DMSO. BF, bright field microscopy; " $\alpha$-1,3-glucan", fluorescence microscopy. AP, appressoria; CO, conidia; GT, germ tube. Scale bar, $20 \mu \mathrm{m}$. More than 300 germinated fungal conidia were observed for each sample. Representative images at $12 \mathrm{~h}$ after incubation are shown. Experiments were repeated three times.

\subsection{Lutein Induced $\alpha-1,3-$ Glucan Accumulation in Cochliobolus Miyabeanus but Not in Magnaporthe oryzae}

Because lutein is the most abundant carotenoid in photosynthetic plant tissues [9], we further tested whether lutein induced $\alpha-1,3$-glucan accumulation on $M$. oryzae and C. miyabeanus, both of which accumulated $\alpha-1,3$-glucan during rice infection [4,5]. Because $M$. oryzae belongs to same subclass as Colletotrichum but C. miyabeanus is phylogenetically distant from Colletotrichum, we speculated that M. oryzae could respond to lutein but not C. miyabeanus. When M. oryzae and C. miyabeanus conidia were incubated on glass coverslips with or without lutein, unexpectedly, cell wall $\alpha-1,3-$ glucan was undetectable in $M$. oryzae but was present in large amounts in $C$. miyabeanus based on the immunofluorescence staining (Figure 5). Thus, C. miyabeanus, but not M. oryzae, responded to lutein as well as Colletotrichum strains to accumulate $\alpha-1,3$-glucan on their surface. 
Control

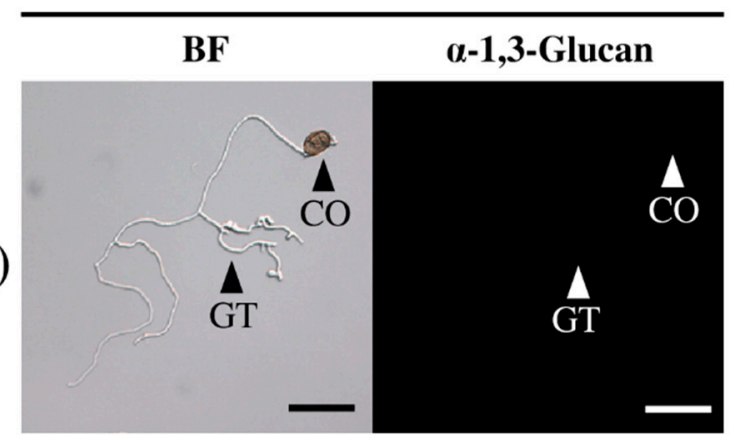

(B)

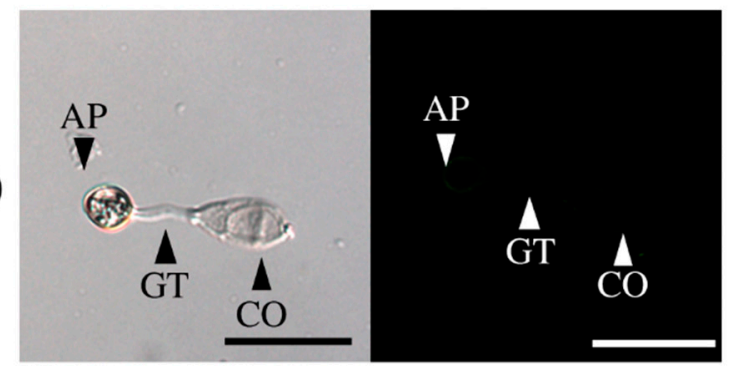

+ Lutein
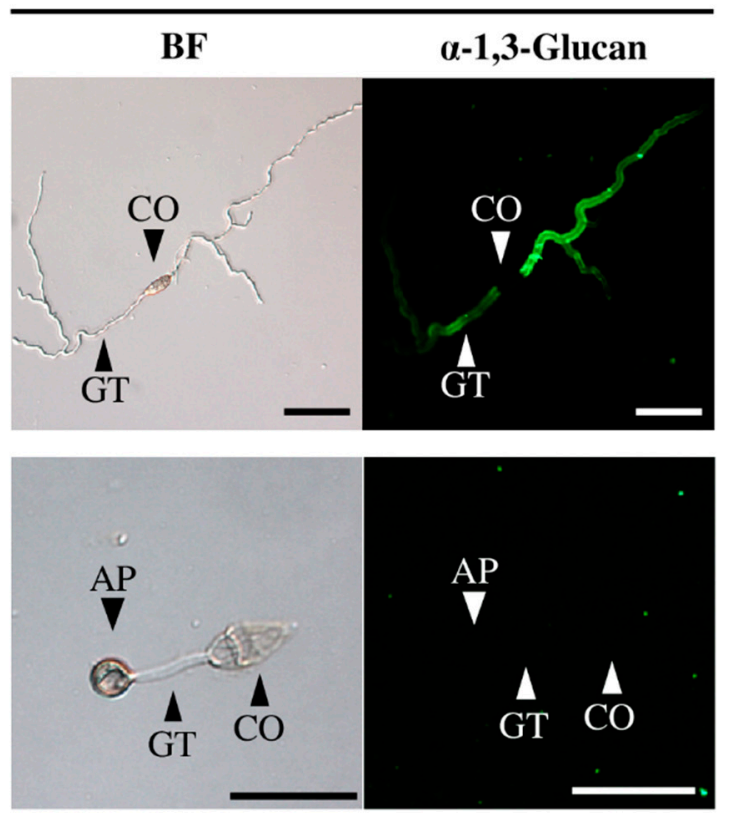

Figure 5. Effect of lutein on the accumulation of $\alpha$-1,3-glucan on the cell walls of Cochliobolus miyabeanus and Magnaporthe oryzae. (A) C. miyabeanus; (B) M. oryzae. Fungal conidia were incubated in $0.24 \%$ potato dextrose broth (PDB) containing stigmasterol $(25 \mu \mathrm{M}$ in $1 \%$ ethanol and $0.1 \%$ dimethyl sulfoxide [DMSO]). Control, $0.24 \%$ PDB containing 1\% ethanol and 0.1\% DMSO. C. miyabeanus accumulated $\alpha-1,3$-glucan on the cell wall in response to lutein, whereas M. oryzae did not. BF, bright field microscopy; “ $\alpha$-1,3-glucan", fluorescence microscopy. AP, appressoria; CO, conidia; GT, germ tubes. Scale bar, $20 \mu \mathrm{m}$. More than 300 germinated fungal conidia were observed for each sample. Representative images at $12 \mathrm{~h}$ after incubation are shown. Experiments were repeated three times.

\subsection{Stigmasterol Showed Induction Activity on Surface $\alpha-1,3-$ Glucan Accumulation in Various Fungi}

Stigmasterol is a major component of plant membranes [10] that fungal plant pathogens may encounter during infection. To examine whether the induction effect was specific to C. fioriniae, $\alpha-1,3$-glucan on the cell wall surfaces of $M$. oryzae and C. miyabeanus incubated in the presence of stigmasterol was detected. Similar to the result obtained with $C$. fioriniae, stigmasterol induced the surface accumulation of $\alpha-1$,3-glucan in these fungi (Figure S3). These results suggested that stigmasterol is a common inducer of surface $\alpha$-1,3-glucan accumulation in various fungal plant pathogens.

\subsection{Surface Accumulation of $\alpha-1,3-$ Glucan Protected the Cell Wall from Digestive Enzymes in Colletotrichum Fioriniae}

The surface accumulated $\alpha-1,3$-glucan protected the cell wall from digestive enzymes in M. oryzae [5]. To test whether the surface $\alpha-1,3$-glucan protected the cell wall in $C$. fioriniae, we treated the fungal mycelia with Uskizyme (Wako Chemicals, Tokyo, Japan), a cocktail of chitinase and $\beta$-1,3-glucanase. As shown in Figure 6, the mycelia grown in the presence of lutein released fewer protoplasts after this enzymatic treatment than those grown in the absence of lutein. This result suggested that the surface accumulation of $\alpha-1,3$-glucan protected the fungal cell wall from digestive enzymes. 


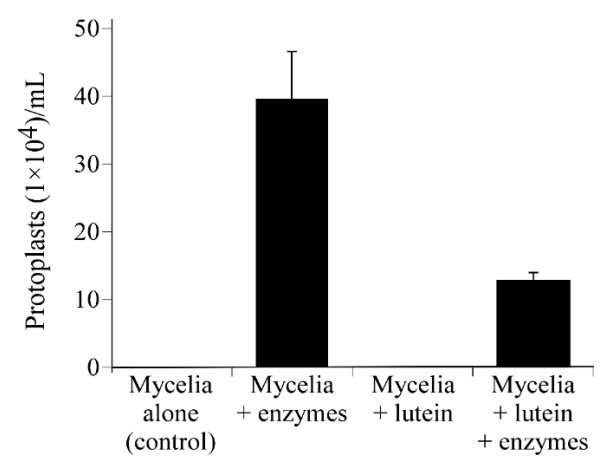

Figure 6. Sensitivity assay to a cell-wall-digesting enzyme cocktail. Number of protoplasts released from Colletotrichum fioriniae cell walls after enzymatic digestion using Uskizyme (a cocktail of $\beta$-1,3-glucanase and chitinase). + enzyme, mycelial samples treated with Uskizyme $(0.5 \mathrm{mg} / \mathrm{mL})$ for $24 \mathrm{~h}$; + lutein, fungal mycelia incubated with lutein $(20 \mu \mathrm{M})$ for $24 \mathrm{~h}$ prior to the enzymatic digestion. The fungal mycelia incubated with lutein released lower numbers of protoplasts after enzymatic treatment.

\section{Discussion}

Fungi are known to reorganize their cell wall components in response to cell wall and plasma membrane perturbation $[3,11,12]$. In this study we identified lutein and stigmasterol, compounds broadly present in plants, as inducers of cell wall reorganization in C. fioriniae; lutein showed greater induction activity than stigmasterol. Notably, lutein induced cell wall reorganization in various Colletotrichum species and C. miyabeanus but hardly in M. oryzae. The fact that the response to lutein was different in these fungi suggesting that presence of lutein is not a general stress factor for the fungal cell wall and the plasma membrane. Similarly, responses to the plant cutin monomer 1,16-hexadecanediol varied in different fungi [4,5]; reorganization of cell wall components was clearly observed with $M$. oryzae [4] but hardly with C. miyabeanus [5] and C. fioriniae. Of note, $\beta$-carotene was not as effective as lutein in C. fioriniae in terms of inducing cell wall reorganization, although these compounds are structurally similar to each other. This result indicated that the difference in the chemical structure between lutein and $\beta$-carotene affected the fungal response. These results would indicate that fungal plant pathogens have mechanisms that allow the fungi to sense specific compounds released from plants.

In contrast to lutein, stigmasterol induced the surface accumulation of $\alpha-1,3$-glucan in various fungi including $M$. oryzae. In addition, ergosterol, a close analog of stigmasterol, showed similar activity to stigmasterol in C. fioriniae. These results suggested that presence of exogenous stigmasterol and its structurally related compounds act as general inducers of cell wall reorganization in fungi. Perturbation of the plasma membrane caused by insertion of amphipathic molecules into the membrane activates cell wall integrity signaling, which regulate the synthesis and reorganization of the cell wall in yeasts [11]. Stigmasterol and ergosterol are amphipathic components of plasma membranes in plant and fungi, respectively [10]. Together, these amphipathic sterols could cause perturbation in the plasma membrane, thereby activating cell wall integrity signaling in these fungal plant pathogens.

Given that these pathogens specifically recognize lutein during infection, how do they access the lutein synthesized and accumulated in plastids in plant cells? It is notable that the infectious life styles of Colletotrichum species are hemibiotrophic, and C. miyabeanus is necrotrophic; these pathogens kill host cells at a certain point during infection $[8,13]$. Lutein could be released from plastids that collapsed as a consequence of fungal killing of the host plant cells. Considering that antifungal enzymes and compounds leak from collapsed vacuoles in dead plant cells [12], the surface $\alpha$-1,3-glucan could facilitate fungal survival by protecting fungal cells during necrotrophic colonization of host cells. Indeed, sensitivity assays against the cell wall digestive enzymes performed in this study indicated that surface $\alpha$-1,3-glucan accumulation protected the fungal cell wall from chitinase and $\beta$-1,3-glucanse, the 
major antifungal enzymes in plants [14]. Stigmasterol released from the plant membrane upon fungal penetration or the membranous collapse of dead plant cells could also facilitate fungal survival during infection via promoting the accumulation of surface $\alpha-1,3$-glucan. Overall, our study suggests that fungal plant pathogens respond to specific factors in plants and modulate their cell wall organization upon infection.

\section{Experimental Section}

\subsection{Fungal Strains and Plant Materials}

All Colletotrichum strains (C. chrysanthemi (MAFF 239363), C. orbiculare (MAFF 240422), C. godetiae (MAFF 241297), C. gloeosporioides (MAFF 306533), C. fioriniae (MAFF 306551)) and C. miyabeanus (MAFF 305425) were obtained from the MAFF gene bank in National Institute of Agrobiological Sciences (Tsukuba, Ibaraki, Japan). Wild-type M. oryzae Guy11 was used for this study. Commercial fresh carrots were supplied as materials for this study.

\subsection{Chemicals}

Lutein and 1,16-hexadecanediol were purchased from United States Biological (Salem, MA, USA) and Tokyo Chemical Industry (Tokyo, Japan), respectively.

\subsection{General}

${ }^{1} \mathrm{H}$ - and ${ }^{13} \mathrm{C}-\mathrm{NMR}(500 \mathrm{MHz}, 125 \mathrm{MHz})$ spectra were recorded on an AV-500 NMR spectrometer (Bruker, Billerica, MA, USA) with $\mathrm{CDCl}_{3}$ as the solvent. The chemical shifts are reported in ppm (parts per million; $\delta$ ), and coupling constants $(J)$ are expressed in Hz. Thin layer chromatography (TLC) was carried out on silica gel 60 F254 (250 $\mu \mathrm{m}$, Merck, Darmstadt, Germany) or silica gel 60 RP-18 F254 $\mathrm{S}(250 \mu \mathrm{m}$, Merck). Flash column chromatography was carried out on silica gel 60 N (40-100 $\mu \mathrm{m}$, Kanto Chemical, Tokyo, Japan). Reversed-phase high-performance liquid chromatography (RP-HPLC) was performed using a Waters 600 HPLC pump/2489 UV/VIS detector (Waters, Milford, MA, USA) computerized data station equipped with Waters Empower-2 software with a reversed-phase column CAPCELL PAK $\mathrm{C}_{18}$ (Shiseido, Tokyo, Japan). Microscopic observation was performed using a Leica DR System with a GFP filter cube (excitation filter BP 470/40 nm, $500 \mathrm{~nm}$ dichromatic mirror, suppression filter BP 525/50 nm) (Leica, Wetzlar, Germany).

\subsection{Extraction and Isolation}

Carrot leaves (706 g) were minced, lyophilized, and then extracted by immersing in $\mathrm{CH}_{2} \mathrm{Cl}_{2} /$ methanol $(\mathrm{MeOH})(1: 1,3 \mathrm{~L})$ for 7 days at room temperature. The extract was filtered and concentrated under reduced pressure ("carrot extract"). The concentrated filtrate was partitioned twice between $n$-hexane $(1 \mathrm{~L}$ ) and $30 \% \mathrm{MeOH}$ aqueous solution $(1 \mathrm{~L})$. The hexane layer was concentrated to obtain $3.59 \mathrm{~g}$ of syrup. The $30 \% \mathrm{MeOH}$ layer was concentrated to remove $\mathrm{MeOH}$, and the remaining aqueous suspension was partitioned twice with ethyl acetate $(1 \mathrm{~L})$. The ethyl acetate layer was evaporated under reduced pressure to obtain $2.23 \mathrm{~g}$ syrup. The aqueous residue was further partitioned with butanol $(1 \mathrm{~L})$ twice to give a $\mathrm{BuOH}$ extract $(1.47 \mathrm{~g})$ and $\mathrm{H}_{2} \mathrm{O}$ residue $(9.20 \mathrm{~g})$. A portion of the hexane layer (LH, $1.20 \mathrm{~g} / 3.59 \mathrm{~g})$ was subjected to silica gel flash column chromatography (50.0 g, $250 \mathrm{~mm} \times 30 \mathrm{~mm}$ i.d., hexane-ethyl acetate, 20:1 (300 mL), 10:1 (300 mL), 5:1 (300 mL), 2:1 (400 mL), 1:1 (400 mL), and $\left.\mathrm{CH}_{2} \mathrm{Cl}_{2}-\mathrm{MeOH}, 10: 1(200 \mathrm{~mL}), 2: 1(300 \mathrm{~mL})\right)$, and fractionated into $20 \mathrm{~mL}$ each to obtain 100 fractions. On the basis of the TLC analyses, all fractions were collected to give 14 fractions (LH-1-14). Fraction LH-11 (19.0 mg), of which $R_{\mathrm{f}}$ value range was from 0.6 to 0.8 by $\mathrm{CH}_{2} \mathrm{Cl}_{2}-\mathrm{MeOH}$ 8:1, was further purified by RP-HPLC (CAPCELL PAK C18, $250 \mathrm{~mm} \times 4.6 \mathrm{~mm}$ i.d., Shiseido, 97.5\% acetonitrile), affording lutein $\left(6.0 \mathrm{mg} ; t_{\mathrm{R}}: 14.3 \mathrm{~min}\right)$. Stigmasterol (50.0 mg) was isolated from fraction LH-8 $\left(R_{\mathrm{f}}\right.$ value range was from 0.5 to 0.7 by hexane-ethyl acetate $\left.2: 1\right)$ via recrystallization twice using hexane and acetone. 
Lutein: Orange powder; ${ }^{1} \mathrm{H}-\mathrm{NMR}\left(\mathrm{CDCl}_{3}\right) \delta 6.66-6.57\left(4 \mathrm{H}, \mathrm{m}, \mathrm{H}-11,11^{\prime}, 15,15^{\prime}\right), 6.35$ (each $1 \mathrm{H}, \mathrm{d}$, $\left.J=15.0 \mathrm{~Hz}, \mathrm{H}-12,12^{\prime}\right), 6.25$ (2H, m, H-14, 14'), 6.13-6.09 (5H, m, H-7, 8, 8', 10, 10'), 5.54 (1H, brs, H-4' $)$, $5.43\left(1 \mathrm{H}, \mathrm{dd}, J=15.5,9.5 \mathrm{~Hz}, \mathrm{H}-7^{\prime}\right), 4.23\left(1 \mathrm{H}, \mathrm{m}, \mathrm{H}-3^{\prime}\right), 4.00(1 \mathrm{H}, \mathrm{m}, \mathrm{H}-3), 2.40\left(1 \mathrm{H}, \mathrm{d}, J=9.5 \mathrm{~Hz}, \mathrm{H}-6^{\prime}\right)$, 2.35-2.28 (1H, m, H-4eq), 2.03 (1H, dd, J = 16.7, 9.7 Hz, H-4ax), 1.97 (3H, s, H-19), 1.96 (6H, brs, H-20, $\left.20^{\prime}\right), 1.91\left(3 \mathrm{H}, \mathrm{s}, \mathrm{H}-19^{\prime}\right), 1.83\left(1 \mathrm{H}, \mathrm{dd}, J=13.5,5.9 \mathrm{~Hz}, \mathrm{H}-2^{\prime} e q\right), 1.74(1 \mathrm{H}, \mathrm{ddd}, J=12.0,3.3,2.1 \mathrm{~Hz}, \mathrm{H}-2 \mathrm{~b})$, $1.73(3 \mathrm{H}, \mathrm{s}, \mathrm{H}-18), 1.62\left(3 \mathrm{H}, \mathrm{s}, \mathrm{H}-18^{\prime}\right), 1.47(1 \mathrm{H}, \mathrm{t}, J=12.0 \mathrm{~Hz}, \mathrm{H}-2 \mathrm{a}), 1.36(1 \mathrm{H}, \mathrm{dd}, J=13.5,7.0 \mathrm{~Hz}$, H-2'ax), 1.07 (6H, brs, C-16, 17), 0.99 (3H, s, C-16'), 0.85 (3H, s, H-17'); ${ }^{13} \mathrm{C}-\mathrm{NMR}\left(\mathrm{CDCl}_{3}\right) \delta 138.6(\mathrm{C}-8)$, 137.9 (C-8'), 137.7 (C-5'), 137.6 (C-6, 9', 12, 12', 13), 136.5 (C-13'), 135.7 (C-9), 132.6 (C-14, 14'), 131.3 (C-10), 130.8 (C-10'), 130.0 (C-15, 15'), 128.7 (C-7'), 126.2 (C-5), 125.6 (C-7), 124.9 (C-4'), 124.9 (C-11), 124.5 (C-11'), 65.9 (C-3'), 65.1 (C-3), 55.0 (C-6'), 48.5 (C-2), 44.7 (C-2'), 42.6 (C-4), 37.1 (C-1), 34.0 (C-1'), 30.3 (C-17), 29.5 (C-16'), 28.7 (C-16), 24.3 (C-17'), 22.9 (C-18'), 21.6 (C-18), 13.1 (C-19'), 12.8 (C-19, 20, $20^{\prime}$ ) (Figure S4).

Stigmasterol: White powder; ${ }^{1} \mathrm{H}-\mathrm{NMR}\left(\mathrm{CDCl}_{3}\right) \delta 5.34(1 \mathrm{H}, \mathrm{brs}, \mathrm{H}-6), 5.14(1 \mathrm{H}, \mathrm{dd}, J=15.0,8.5 \mathrm{~Hz}, \mathrm{H}-23)$, $5.01(1 \mathrm{H}, \mathrm{dd}, J=15.0,8.5 \mathrm{~Hz}, \mathrm{H}-22), 3.52(1 \mathrm{H}, \mathrm{tt}, J=11.0,4.5 \mathrm{~Hz}, \mathrm{H}-3), 2.30-2.21(4 \mathrm{H}, \mathrm{m}, \mathrm{H}-4,20,24)$, 2.01-1.94 (3H, m, H-7, 25), 1.01-1.03 (6H, brs, H-19, 21), 0.92 (3H, d, 5.0 Hz, H-26), 0.83 (3H, dd, J = 7.5, $7.5 \mathrm{~Hz}, \mathrm{H}-29), 0.81(3 \mathrm{H}, \mathrm{d}, J=5.0 \mathrm{~Hz}, \mathrm{H}-27), 0.67(3 \mathrm{H}, \mathrm{s}, \mathrm{H}-18),{ }^{13} \mathrm{C}-\mathrm{NMR}\left(\mathrm{CDCl}_{3}\right) \delta 140.8(\mathrm{C}-5), 138.3$ (C-22), 129.3 (C-23), 121.7 (C-6), 71.8 (C-3), 56.8 (C-14), 56.1 (C-17), 51.2 (C-24), 50.2 (C-9), 45.6 (C-4), 42.3 (C-13), 40.5 (C-20), 39.8 (C-12), 37.3 (C-1), 36.5 (C-10), 36.2 (C-8), 33.9 (C-25), 32.0 (C-2, 7), 28.3 (C-16), 26.1 (C-28), 24.3 (C-15), 23.1 (C-21), 21.1 (C-26), 19.8 (C-14), 19.4 (C-19), 19.0 (C-27), 18.8 (C-11), 12.3 (C-29), 12.0 (C-18) (Figure S5).

\subsection{Immunofluorescent Staining of Fungal Cell Wall $\alpha-1,3-$-Glucan}

The Colletotrichum strains were grown on potato dextrose agar (PDA; BD Difco, Franklin Lakes, $\mathrm{NJ}$, USA) at $25^{\circ} \mathrm{C}$ with constant near-ultra violet (UV) irradiation for 5 days to induce conidiation. The $\mathrm{C}$. miyabeanus strain was first grown on PDA at $25^{\circ} \mathrm{C}$ with constant fluorescence for 5 days followed by further incubation at $20^{\circ} \mathrm{C}$ with constant near-UV irradiation for 7 days to induce conidiation. The M. oryzae strain was incubated on oatmeal agar media ( $3 \%$ oatmeal and $1.6 \%$ agar) at $25^{\circ} \mathrm{C}$ with constant fluorescence for 7 days to induce conidiation. The fungal conidia were suspended in $0.24 \%$ potato dextrose broth (PDB; BD Difco) aqueous solution at a concentration of $2 \times 10^{5}$ conidia/mL. For the bioassays, aliquots of the samples from each fraction were dissolved in ethanol containing $10 \%$ dimethyl sulfoxide (DMSO) at a concentration of $1000 \mathrm{ppm}$. The sample solutions were added to conidial suspensions at a final concentration of $10 \mathrm{ppm}$ (100-fold dilution). The sample/conidia mixture $(50 \mu \mathrm{L})$ was dropped onto a cover glass (Matsunami, Osaka, Japan) and incubated for $12 \mathrm{~h}$ at $20{ }^{\circ} \mathrm{C}$ in a moist chamber in the dark. Fungal cells were then rinsed lightly with PBS buffer composed of $\mathrm{NaCl}(80.0 \mathrm{~g} / \mathrm{L}), \mathrm{Na}_{2} \mathrm{HPO}_{4} \cdot 12 \mathrm{H}_{2} \mathrm{O}(29.0 \mathrm{~g} / \mathrm{L}), \mathrm{KCl}(2.0 \mathrm{~g} / \mathrm{L})$, and $\mathrm{KH}_{2} \mathrm{PO}_{4}(2.0 \mathrm{~g} / \mathrm{L})$.

In the following assays, commercially available lutein and purified stigmasterol were used. To detect $\alpha$-1,3-glucan on Colletotrichum strains, $30 \mu \mathrm{L}$ of the primary antibody solution $(0.1 \mathrm{mg} / \mathrm{mL}$ of IgM $\gamma$ MOPC-104E (Sigma, St. Louis, MO, USA) in PBS buffer) was first dropped onto the fungal cells and incubated for $4 \mathrm{~h}$ at room temperature in the dark. The samples were rinsed with PBS buffer followed by a $1 \mathrm{~h}$ incubation with $20 \mu \mathrm{L}$ fluorescein isothiocyanate (FITC)-conjugated secondary antibody $(0.1 \mathrm{mg} / \mathrm{mL}$ of rabbit anti-mouse IgM, $\mu$ chain specific, Jackson ImmunoResearch, West Grove, PA, USA) in PBS buffer in the dark at room temperature. Detection of $\alpha$-1,3-glucan on M. oryzae and C. miyabeanus was performed as described in Fujikawa et al. [4,5]. Samples were rinsed with PBS buffer before microscopic observation using a Leica DR system.

\subsection{Sensitivity Assay to Cell Wall Digesting Enzymes}

C. fioriniae conidia were incubated in PD medium $\left(1 \times 10^{5} / \mathrm{mL}\right)$ for $24 \mathrm{~h}$ followed by additional incubation for $24 \mathrm{~h}$ in the presence or absence of $20 \mu \mathrm{M}$ lutein at $25^{\circ} \mathrm{C}$ in the dark. The fungal mycelia were washed twice with 1.2 M sorbitol in $1 \mathrm{mM}$ PIPES (pH 6.5) before being digested with Uskizyme 
(Wako, Osaka, Japan) (0.5 mg/mL 1.2 M sorbitol in $1 \mathrm{mM}$ PIPES, pH 6.5) at $28^{\circ} \mathrm{C}$ for $24 \mathrm{~h}$ in the dark. Uskizyme is an enzyme cocktail of $>5000$ units/g of $\beta-1,3$-glucanase and $>30$ units/g of chitinase. Numbers of generated protoplasts were counted using a hemocytometer.

\section{Conclusions}

Fungal plant pathogens reorganize their cell wall components in response to specific plant-derived compounds such as carotenoids.

Supplementary Materials: Supplementary materials can be accessed at: http:/ /www.mdpi.com/1420-3049/ 21/8/980/s1.

Acknowledgments: This work was supported by JSPS KAKENHI Grant Number 26292028.

Author Contributions: M.N., S.S. and J.O. designed the experiments. J.O. performed the experiments and data analysis. J.O., M.N. and S.S wrote the manuscript.

Conflicts of Interest: The authors declare no conflict of interest.

\section{References}

1. Latgé, J.P. Tasting the Fungal Cell Wall. Cell. Mocrobiol. 2010, 12, 863-872. [CrossRef] [PubMed]

2. Free, S.J. Fungal Cell Wall Organization and Biosynthesis. Adv. Genet. 2013, 81, 33-82. [PubMed]

3. Latgé, J.P.; Bauvais, A. Functional duality of the cell wall. Curr. Opin. Microbiol. 2014, 20, 111-117. [CrossRef] [PubMed]

4. Fujikawa, T.; Kuga, Y.; Yano, S.; Yoshimi, A.; Tachiki, T.; Abe, K.; Nishimura, M. Dynamics of Cell Wall Components of Magnaporthe grisea during Infectious Structure Development. Mol. Microbiol. 2009, 73, 553-570. [CrossRef] [PubMed]

5. Fujikawa, T.; Sakaguchi, A.; Nishizawa, Y.; Kouzai, Y.; Minami, E.; Yano, S.; Koga, H.; Meshi, T.; Nishimura, M. Surface $\alpha-1,3$-Glucan facilitates fungal stealth infection by interfering with innate immunity in plants. PLoS Pathog. 2012, 8e1002882. [CrossRef] [PubMed]

6. Hyde, K.D.; Cai, L.; Cannon, P.F.; Crouch, J.A.; Crous, P.W.; Damm, U.; Goodwin, P.H.; Chen, H.; Johnston, P.R.; Jones, E.B.G.; et al. Colletotrichum-Names in current use. Fungal Divers. 2009, 39, 147-182.

7. Damm, U.; Cannon, P.F.; Woudenberg, J.H.C.; Crous, P.W. The Colletotrichum acutatum species complex. Stud. Mycol. 2012, 73, 37-113. [CrossRef] [PubMed]

8. Cannon, P.F.; Damm, P.R.; Johnson, P.R.; Weir, B.S. Colletotrichum-Current status and future directions. Stud. Mycol. 2012, 73, 181-213. [CrossRef] [PubMed]

9. Kim, J.; DellaPenna, D. Defining the Primary Route for Lutein Synthesis in Plants: The Role of Arabidopsis Carotenoid $\beta$-ring hydroxylase CYP97A3. Proc. Natl. Acad. Sci. USA 2006, 103, 3474-3479. [CrossRef] [PubMed]

10. Hartman, M.-A. Plant sterols and the membrane environment. Trends Plant Sci. 1998, 3, 170-174. [CrossRef]

11. Levin, D.E. Regulation of cell wall biogenesis in Saccharomyces cerevisiae: The cell wall integrity signaling pathway. Genetics 2011, 189, 1145-1175. [CrossRef] [PubMed]

12. Yoshimi, A.; Miyazawa, K.; Abe, K. Cell wall structure and biogenesis in Aspergillus species. Biosci. Biotechnol. Biochem. 2016, 3, 1-12. [CrossRef] [PubMed]

13. Condon, B.J.; Leng, Y.; Wu, D.; Bushley, K.E.; Ohm, R.A.; Otillar, R.; Martin, J.; Schackwitz, W.; Grimwood, J.; MohdZainudin, N.; et al. Comparative Genome Structure, Secondary Metabolite, and Effector Coding Capacity across Cochliobolus Pathogens. PLoS Genet. 2013, 9e1003233. [CrossRef] [PubMed]

14. Van Doorn, W.G.; Beers, E.P.; Dangl, J.L.; Franklin-Tong, V.E.; Gallois, P.; Hara-Nishimura, I.; Jones, A.M.; Kawai-Yamada, M.; Lam, E.; Mundy, J.; et al. Morphological classification of plant cell deaths. Cell Death Differ. 2011, 18, 1241-1246. [CrossRef] [PubMed]

Sample Availability: The samples of compounds used in this study are available from the authors upon request.

(C) 2016 by the authors; licensee MDPI, Basel, Switzerland. This article is an open access article distributed under the terms and conditions of the Creative Commons Attribution (CC-BY) license (http://creativecommons.org/licenses/by/4.0/). 